\title{
THE NEW "SILK ROAD”: GLOBAL ASPECT, EU POSITION AND ECONOMIC ROLE OF SERBIA
}

\author{
Filip Ž. Bugarčić ${ }^{1}$, Daiva Jurevičiené2 $\dot{2}^{2}$ Nenad Janković \\ ${ }^{1}$ Faculty of Economics, University of Kragujevac, Liceja Kneževine Srbije 3, Kragujevac, Serbia \\ ${ }^{2}$ Department of Economics Engineering, Vilnius Gediminas Technical University, \\ Sauletekio al. 11, Vilnius, Lithuania \\ ${ }^{3}$ Faculty of Economics, University of Kragujevac, Liceja Kneževine Srbije 3, Kragujevac, Serbia \\ E-mails: ${ }^{1}$ f.bugarcic@kg.ac.rs (corresponding author); ${ }^{2}$ daiva.jureviciene@vgtu.lt; ${ }^{3}$ njankovic@kg.ac.rs
}

Received 26 March 2020; accepted 06 May 2020

\begin{abstract}
More active participation of China in the international economy has been recognized by European countries, trying to position their economies on the new "Silk Road" map to attract Chinese investments and increase trade volume. The paper presents previous researches and analyses the position, benefits and chances for EU and Serbia to derive positive economic effects from this initiative. The research purpose is to point out the impact of "Silk Road" on the Serbian economy. The main findings are highlighting the advantages and disadvantages using analysis of scientific literature and emphasising the increase in investments and trade volume of Serbia with China using statistical analysis for the period after the initiative started in 2013.
\end{abstract}

Keywords: new "Silk Road", international trade, China, EU, CEEC, Serbia.

JEL Classification: F2, F14, F43.

\section{Introduction}

In current economic circumstances, the world economies are forced to find a new pattern for continuous economic growth, increasing the volume of international trade and access new markets. A new tendency for the European and Asian economies is to revive former trade routes between China and countries on the European continent, popularly called "One belt, one road" or "New Silk Road" initiative. As part of its development strategy, the People's Republic of China launched the new Silk Road initiative in 2013, which connects three continents with trade routes: Asia, Europe and Africa. This challenging project will initiate the development of the world's most significant infrastructure corridor that will bring together 4.4 billion people and economies worth $\$ 21,000$ billion (Hedge, 2017). Such a "belt" will allow more than half of the world's current population to interact and connect many countries. In this way, space is opened to eliminate trade barriers and create a more efficient flow of goods, capital and people.

The vigorous development of China's economy at the beginning of the 21 st century has made China a more attractive economic partner when it comes to trade and investment (Dimitrijević \& Jokanović, 2016). The ancient Silk Road has again become attractive, through the desire for a level of land infrastructure projects and through the intensification of the maritime route, which would cover the maximum number of countries between China and Western Europe. The new Silk Road economic belt contributes to countries to interact with each other, develop strategies, making standard plans and work to improve road infrastructure (Simić, 2015). Besides, trade facilitation is needed, which implies that all parties should consider trade and investment issues, as well as strengthening competition throughout the region.

This integration strategy can provide multiple benefits for European and Central Asian countries. Still, it will also help Chinese companies to achieve their global business strategies and investments to new markets. Through this initiative, access to them will be greatly facilitated, and individual Chinese companies' goals will benefit the whole economy. For this reason, it is not surprising that the Chinese Government and investors give financial support to many different projects (Žujović, 2015). When it comes to European economies, especially the countries of Central and SouthEastern Europe, membership and aspiration for existing European integrations on the territory of Europe is slowly beginning to draw on its capacities. The declining growth rates and the need for new investments and access to new markets give a strong motivation to countries to join the new 
global economic integration with China and other countries along the way. Among the countries of the region of South-Eastern Europe, especially the countries of the Western Balkans, Serbia has a chance to intensively join the new development plan, primarily through locating internal potentials and international logistics position. There is a need to monitor this initiative. At the same time, the existing literature does not show in sufficient detail the trend of countries' development due to participation in the Silk Road. This article supplements the research with an insight on the Serbian economy after launching this initiative and analysing its economic impact. The subject of the article is the importance of the new Silk Road for development strategies of national economies along the way, and therefore the national economy of Serbia. The aim of the paper is to highlight the impacts and effects of this initiative on the Serbian economy, from its inception in 2013 to the present.

The article consists of five parts. After the introduction, the theoretical approach of the new Silk Road is presented. The third section offers the analysis of statistical data, and the fourth part of the paper is focused on cooperation between Serbia and China, followed by concluding considerations and outlines of potential further research in the fifth part.

\section{Theoretical approach}

An essential diplomatic goal and long-term priority of China's foreign policy is the use of BRI to build and promote China's role in the global economy (Chen, 2017). This initiative provides an opportunity for China to realize a comprehensive development strategy and achieve the goals of influencing other economies, thereby meeting its interest (Xia \& Shen, 2016). Rimmer (2018) and Rifkin (2016) point out that the new Silk Road will contribute to intensifying air and rail transport, energy and resource cooperation, and bringing all countries within this initiative closer together on modern technologies, digital and technological integration. Elek et al. (2017) conclude that soon, this initiative has potential to contribute to the inclusion of all economies along the way in creating a global value chain through improved logistics and global economic connectivity and cooperation.

$\mathrm{Li}$ and Schmerer (2017) have analysed the importance of this initiative on trade and economic opportunity. BRI initiative aims to integrate China into the world economy by promoting conventional economic policies, improving connectivity between remote locations, smooth trade and connect- ing people. This strategy primarily aims at accelerated economic growth and development. Besides, the authors emphasize that despite the enormous potential of this initiative, there are reasons to believe that the implementation will not be easy. Authors Dorn and Hanson (2011) proved that imports from China are destroying US jobs while highlighting the negative consequences of such cooperation. Dauth et al. (2016) have shown, on the example of the German economy, that the positive effects of exports outweigh the harmful effects of imports, and that trade cooperation with China has led to 3 million jobs dependent on sales in the Chinese market, while also gaining competitive advantages for European companies. Besides, Chinese imports have also led to an increase in innovation, productivity and modern technology (Bloom et al., 2016).

One of the critical pieces of evidence in the existing trade facilitation literature is related to the reduction of transport costs in transporting goods due to investment in infrastructure upgrades. Egger and Larch (2008) have proved through the gravity model of international trade that investment in railway infrastructure contributes to a significant increase in trade. Suitable transport infrastructure and logistics solutions are the crucial determinants of a country's ability to participate in the global economy. Limao and Venables (2001) estimated that an increase in transportation costs of $10 \%$ could lead to a decrease in trade by as much as 20\%. This evidence justifies the efforts of Chinese investment ventures to improve rail infrastructure along the entire "belt". Li and Huang (2019) conclude that the initiative of the new Silk Road has established significant networks of connectivity and trade and at the same time stimulated the economic and financial development of countries along this route in terms of infrastructure construction, connectivity, capital and FDI flows. Chinese investors have thus established cooperation with other countries along this path to implement their strategies and expand the Chinese market and influencing the West.

It is a fact that most countries, in cooperation with China, increase imports more than increase exports (Nazarko et al., 2017). China's economic and trade cooperation with European economies is mainly present in bilateral relations with Germany, the United Kingdom and other developed Western European countries. As regards the countries of Central and Eastern Europe (CEEC), their cooperation with China is lower than the developed EU countries. Still, there is a trend of increasing international economic relations after the introduction 
of "One Belt One Road" initiative. According to Odrijas (2018), more in-depth cooperation with China is desirable for CEEC to diversify trading and investment partners. It leads to greater economic interdependence and integration, with mutual benefits. In this way, China intensifies its relations with CEE countries $(16+1)$, gaining access to new markets, and in turn, provides an opportunity for these countries to make new investments and intensify trade. As a condition and necessity of this cooperation, the improvement of logistics performance is foremost imposed, especially for CEE countries, which are not currently EU members. It would increase transport efficiency and improve logistics services to a level that ensures the smooth transport of goods through their territory (Nazarko et al., 2017).

All advantages, as mentioned above, could be generalized (Figure 1).

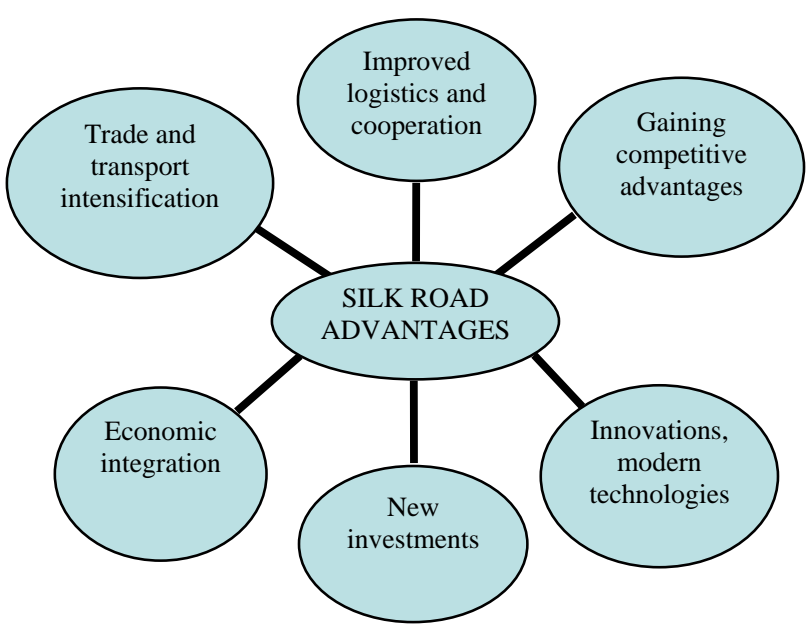

Figure 1. Silk Road advantages (created by authors)

Summarizing literature review, we can conclude that cooperation via "Silk Road" has a positive impact on European economies (especially advanced) despite potential threat on the jobs market. However, this possible hazard could positively affect the job market due to the increase in sales with the most significant economy in terms of population.

\section{Analysis of statistical data}

There are many interpretations of the ultimate goals of the initiative, but one is clear. The "Belt and Road" initiative can bring essential improvements in regional and international connectivity by improving infrastructure and facilitating trade in a vast geographical area. This belt covers 63 countries, $60 \%$ of the world's population and $30 \%$ of global GDP (World Economic Forum, 2016). The project focuses on two significant routes along which connectivity should be fostered: land and sea. Onshore, the focus is on transport infrastructure and energy. At sea, investments in ports and new trading routes are the main pillars (Paulain, 2011).

The project also includes rail transport, which began in 2011 when Chinese freight trains began operating on the Chongqing-Duisburg line via Kazakhstan, Russia, Belarus and Poland. This section shortened the journey time of Chinese goods from Shanghai and Guangzhou from the 36 days required by ship to 12 days by a freight train and lowered the cost of transportation (Marić, 2017). The importance of enhancing China's and the European Union's ties is the fact that the EU is China's largest trading partner and a large market for Chinese goods. Most trade is related to industrial products, and according to the European Commission, EU exports to China have increased by $38 \%$ since 2010, while Chinese exports have increased by $31 \%$ (European Commission, 2019). The effects of integration have been visible long and give a right impetus to the further convergence of the two economies, as well as the other countries between them. China's importance as a trading partner can also be seen in the increasing international trade of individual countries. Figure 2 shows that lately, countries trade less with USA and more with China.

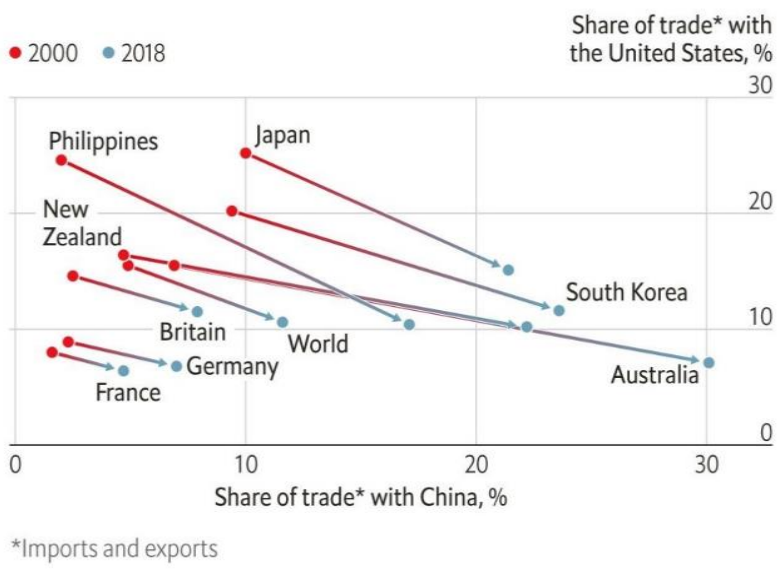

Figure 2. Countries' share of trade with China and the USA, 2000 (in red) and 2018 (in green) (source: The Economist, 2019)

China's move to the west and the European Union could be viewed in three directions (Simić, 2015):

- the first, towards the EU headquarters, Brussels and the most economically advanced member states (EU15); 
- the second, towards the EU member states of Central and Eastern Europe;

- the third track is directed towards the countries of Southeast Europe, which are not yet EU members.

The Chinese model of foreign aid and investment is based on the Beijing Consensus. It includes three principles (Marić, 2017):

- Innovation and adaptability to local conditions;

- Sustainability and stability (investment in infrastructure and natural resources);

- Maintaining independence (noninterference in internal politics).

The European Union, USA and China account for the largest share of world trade in goods, accounting for $43 \%$ of global goods exports and $46 \%$ of global imports (Eurostat, 2019). China (16.8\%) has the largest share of world exports, with an always-present surplus in the trade balance, which has been increasing especially since 2013. The EU (15.6\%) and the United States (11.2\%) follow China. In terms of world imports, the largest share is in the US (17\%), ahead of the EU (15.2\%) and China $(13.9 \%)$. Detailed insight into the importance of China-EU relations can be seen by monitoring foreign trade indicators, international trade in goods and services, as well as foreign direct investment between the two economies. The European Commission's report latest data are presented in Table 1.

Table 1. Trade in goods, services, the EU-China FDI ratio, in billions of euros, 2016-2018 (source: European Commission, 2019)

\begin{tabular}{|c|c|c|c|}
\hline \multicolumn{4}{|c|}{ Trade in goods } \\
\hline Year & $\begin{array}{l}\text { Import from } \\
\text { China }\end{array}$ & $\begin{array}{l}\text { Export to } \\
\text { China }\end{array}$ & Balance \\
\hline 2016 & 352.3 & 169.7 & -182.6 \\
\hline 2017 & 375.4 & 197.6 & -177.7 \\
\hline 2018 & 394.8 & 209.9 & -184.9 \\
\hline \multicolumn{4}{|c|}{ Trade in services } \\
\hline Year & $\begin{array}{c}\text { Import from } \\
\text { China }\end{array}$ & $\begin{array}{c}\text { Export to } \\
\text { China }\end{array}$ & Balance \\
\hline 2016 & 28.4 & 42.9 & 14.5 \\
\hline 2017 & 32.2 & 42.8 & 10.6 \\
\hline 2018 & 30.6 & 46.7 & 16 \\
\hline \multicolumn{4}{|c|}{ FDI } \\
\hline Year & $\begin{array}{c}\text { China's FDI } \\
\text { in EU }\end{array}$ & $\begin{array}{c}\text { EU's FDI in } \\
\text { China }\end{array}$ & Balance \\
\hline 2017 & 59.7 & 176.1 & 116.4 \\
\hline
\end{tabular}

On average, China and Europe trade in goods and services worth one billion euros a day. The main EU imports from China are industrial and consumer goods, machinery and equipment, footwear and clothing. The main EU exports to China are machinery and equipment, motor vehicles, aircraft and chemicals (European Commission, 2019). Data in Table 1 show that the value of total foreign trade has a growing trend. The EU has a deficit in trade in goods, while the trade in services deficit is on China's side. The latest available European Commission figures on total FDI between China and the EU show EU's foreign direct investment in China are more significant for $€ 116.4$ billion. This data points to the considerable presence of EU capital in China, which may be one of the tasks for China's strategy to balance this relationship.

In 2016, the EU adopted a new strategy that sets out the EU's relationship with China over the next five years. The plan promotes reciprocity, a level playing field and fair competition in all areas of cooperation. Trade plan is focused on improving market access opportunities. Negotiations on the Investment Agreement began in 2013. The negotiations aim to enhance investments for European and Chinese investors by creating the right to invest and guaranteeing non-discrimination, improving transparency, licensing and authorization procedures, ensuring a high and balanced level of investor and investment protection, as well as introducing rules on environmental and labour aspects of foreign investment (European Commission, 2019).

In addition to China's cooperation with the most developed EU countries, it also includes the "16 + 1" policy (Simić, 2015). This cooperation consists of a credit line from Chinese banks for investments in the field of infrastructure and development projects, as well as collaboration in the areas of science, technology and research projects. The first Summit of Leaders of China and CEE Countries was held in Warsaw in 2012. The initiative consisted of 12 points covering the establishment of a $\$ 10$ billion exclusive credit line for CEE countries. Investment Cooperation Fund between China and CEE planned to (Szczudlik-Tatar, 2013):

- raise $\$ 500$ million in the first phase;

- increasing total trade between to $\$ 100$ billion by 2015 ;

- encouraging Chinese companies to invest in specific economic and technological zones in CEE and

- exploring potential financial cooperation.

In 2013 and 2014 were held the second and third summits to enhance collaboration. 
Empirical evidence shows that the volume of trade between China and CEEC increased significantly before 2012, but after that, it increased at a slightly slower pace (Figure 3 ) (the last available data are for 2016). Chinese exports to CEE countries were expanding much faster from their export to China, thus creating an imbalanced trade, which is substantial to China's benefit. International trade between China and CEEC reached $€ 57.3$ billion in 2017, a small amount compared to the total EUChina trade of $€ 573$ billion. This amount of foreign trade is far less than the initial target of reaching the US $\$ 100$ billion by 2015. Between 2012 and 2017, international trade between China and CEEC increased by only 7 billion euros, at a much slower pace than in the previous three years (20102012) when it increased by 20 billion euros (European Parliament, 2018).

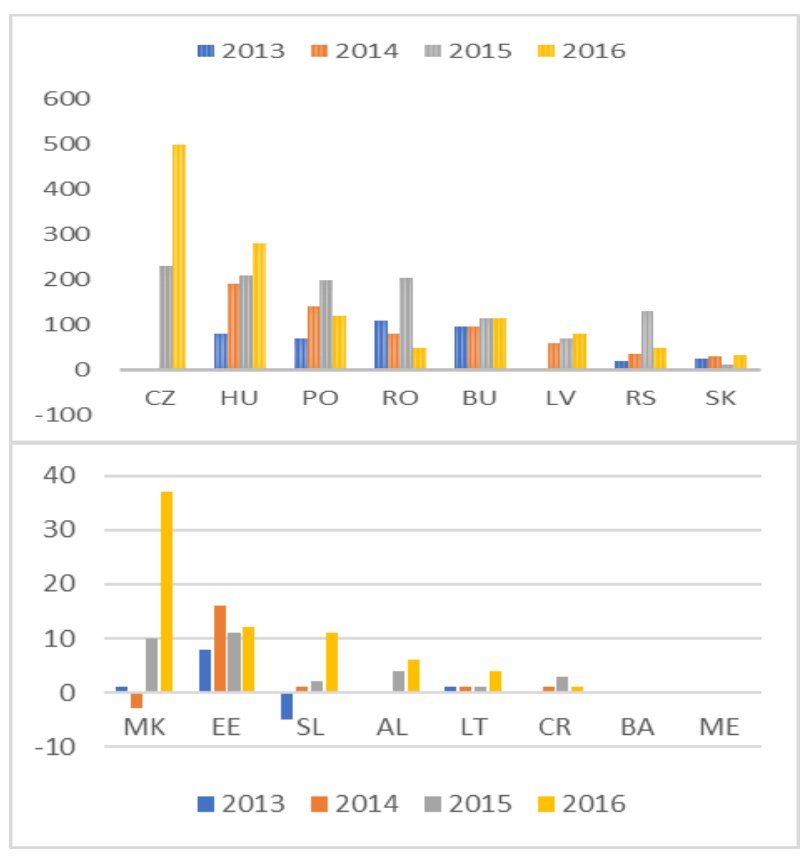

Figure 3. Chinese FDI stock in Central and Eastern European countries, in millions of euros in 2013-2016 (source: European Parliament, 2018)

Data from Figure 3 reveal that Chinese FDI stock is highly concentrated in the largest countries of the CEE region. Some smaller nations in this block have also begun to attract Chinese FDI but at relatively low levels.

\section{Results of China - Serbia cooperation}

Regarding the concrete results of the agreement so far under the " $16+1$ " policy for the Serbian economy, China announced new investments in CEEC at the Belgrade Summit in 2014. The most significant emphasis is on the project of modernization the Bel-
grade-Budapest railway. The project cost is between 1.5 and 2 billion euros and shortens the travel time from 8 to 2.4 hours. After that, it is planned to extend the railway and connect Skoplje and Athens. China sees the railroad as a possible "land and sea express line" between China and Europe (Zeldin, 2015). This agreement clearly shows the role of Serbia in logistics significance on the new Silk Road. Development of road and railway infrastructure is especially emphasized as the essential factor for Serbia and the first step of joining the BRI. As a potential EU member state, with close relations and political support from China, Serbia has the opportunity to participate in its economic integration and to cooperate with both economies actively.

One of the moves of China's strategy in the Southeast European region is the acquisition of a majority stake in the ports of Piraeus (Greece) and Kumport (Turkey) by Chinese investors as a form of logistics tactics for accessing the European market. The bulk of container shipping will find its way through the land infrastructure of Serbia, so it is not surprising that Chinese investors are interested in investing in railway infrastructure and reducing the time of transport through Serbia to EU countries. Piraeus port is the most frequent passenger port in Europe, and container transhipment at the port has been increasing since 2009. According to Lloyd's container port list, Piraeus ranks eighth in Europe and third in the Mediterranean (Mišev et al., 2017).

The share of railway transport in the total freight flows in the Serbian market is between 10 and $15 \%$, while the prospect of railway improvement is far greater. As of 2017, Serbian Railways has increasing transport to the ports of Piraeus, Rijeka, Burgos and Bar (Mišev et al., 2017). Road traffic in Serbia, in last ten years, increased by 11 million vehicles $(34.15 \%)$, and the trend of increasing from $1-2 \%$ (annually) has jumped rapidly to $5-10 \%$ in the last few years (JP Putevi Srbije, 2018). The implementation of projects on the development of road infrastructure in the territory of Serbia enables faster and more efficient traffic of goods. An overview of goods traffic through Serbia is given in Table 2 .

Table 2. Overview of transported goods through the territory of Serbia, goods in millions of tones, 20132019 (source: Statistical Office of the Republic of Serbia, 2020)

\begin{tabular}{|c|c|c|c|c|c|c|c|}
\hline Year & 2013 & 2014 & 2015 & 2016 & 2017 & 2018 & 2019 \\
\hline $\begin{array}{l}\text { Goods } \\
\text { (mil t) }\end{array}$ & 24.3 & 24.7 & 26.6 & 29.4 & 30.0 & 32.8 & 34.1 \\
\hline
\end{tabular}


Improving transport infrastructure, with low taxes, skilled labour with lower wages compared to EU level and direct access to the EU market, are additional reasons for Serbia-China cooperation. Serbia is essential to China because it has signed a free trade agreement with CEFTA and EFTA countries, Turkey, the Customs Union comprising Russia, Belarus and Kazakhstan, as well as a trade agreement with the EU, which indirectly provides market access to over one billion people cleared of customs. Through such a channel, China could quickly enter all these markets, use the benefits of these trade arrangements for their products placement, and satisfy Chinese interests (Ladjevac \& Djordjević, 2016).

Serbia's largest export markets are EU and Balkan countries. In terms of imports, followed by Germany and Italy, China is the third country from which Serbia imports goods. The value of imports from China is about the US $\$ 2.507$ million, and the deficit is on the side of Serbia for the US \$2.178 million (Statistical Office of the Republic of Serbia, 2020), which is sufficient evidence of the vast differences between these two economies and Serbian dependence on imports from China. China's percentage share in total Serbian imports is $8.4 \%$. From 2014 to 2018 imports from China to Serbia increased by $39 \%$ (from $\$ 1.5$ billion to $\$ 2.1$ billion), which is not surprising given the fact that, according to the ranking of countries in total world exports, China is on the first place in the world with $17 \%$ of total world exports (International Trading Centre, 2019).

Logistics indicators are an essential parameter in active participation in Silk Road. The efforts of Chinese investors are focused on improving logistics performances, on making international trade as fast and secure as possible. Logistics Performance Index (LPI) allows identifying areas where economic growth can be constrained by inadequate logistics performance (Jane, 2011). This index is a multidimensional logistic performance rating, expressed on a scale of 1 (lowest score) to 5 (highest rating) - countries with a higher LPI character lower trade costs and more significant opportunity to reach foreign markets. Table 3 gives an insight into the position of Serbia and China, according to the LPI index (World Bank, 2019) (LPI index is published once every two years).

Besides, foreign investment plays a vital role in the Serbian strategy of economic development. As an instrument of economic recovery, FDIs enable to enhance the competitive advantage, facilitate access to international markets, and serve to improve the country's balance of payments. Chinese assistance is necessary for realizing those goals (Dimitrijević, 2018). The result of the cooperation with China should aim in economic growth and long-term positive effects on the domestic infrastructure and the possibility of intensifying foreign trade relations with other countries within the "Belt and Road" initiative.

Table 3. Values of the LPI, Serbia and China, 2018 (source: World Bank, 2019)

\begin{tabular}{|l|c|c|}
\hline \multicolumn{1}{|c|}{ Country } & China & Serbia \\
\hline Year & 2018 & 2018 \\
\hline LPI rank & 26 & 65 \\
\hline LPI score & 3.61 & 2.84 \\
\hline Customs & 3.29 & 2.6 \\
\hline Infrastracture & 3.75 & 2.6 \\
\hline International shipments & 3.54 & 2.97 \\
\hline Logistics competence & 3.59 & 2.7 \\
\hline Tracking \& tracing & 3.65 & 2.79 \\
\hline Timelines & 3.84 & 3.33 \\
\hline
\end{tabular}

Based on cooperation through this initiative, about $€ 2$ billion has been transferred from China to Serbia. Of that amount, a quarter relates to FDI and the remaining part to loans given to Serbia (Narodna Banka Srbije, 2019). Considering the volume mentioned above of foreign trade between the two countries, Chinese exports to Serbia increased by about US $\$ 1$ billion. In contrast, exports from Serbia to China increased by approximately US \$1 billion. Detailed annual data are presented in Table 4. In comparison, exports from Serbia to China increased by about US $\$ 320$ million (Statistical Office of the Republic of Serbia, 2020); it can be stated that the increased inflow of investments from China contributed to the increase in the volume of foreign trade between Serbia and China.

Table 4. Serbia-China foreign trade data, millions of US dollars, 2013-2019 (source: Statistical Office of the Republic of Serbia, 2020)

\begin{tabular}{|c|c|c|c|c|c|}
\hline Year & $\begin{array}{c}\text { Ex- } \\
\text { port }\end{array}$ & $\begin{array}{c}\text { Im- } \\
\text { port }\end{array}$ & Balance & $\begin{array}{c}\sum \text { chan } \\
\text { ge in } \\
\text { goods }\end{array}$ & $\begin{array}{c}\text { Imp/ } \\
\text { exp \% }\end{array}$ \\
\hline 2013 & 9 & 1.510 & -1.501 & 1.519 & 0.6 \\
\hline 2014 & 14.1 & 1.561 & -1.547 & 1.571 & 0.9 \\
\hline 2015 & 20.2 & 1.466 & -1.445 & 1.486 & 1.4 \\
\hline 2016 & 25.3 & 1.522 & -1.497 & 1.548 & 1.7 \\
\hline 2017 & 62.2 & 1.768 & -1.706 & 1.830 & 3.5 \\
\hline 2018 & 91.7 & 2.167 & -2.076 & 2.260 & 4.2 \\
\hline 2019 & 329.9 & 2.507 & -2.178 & 2.837 & 13.2 \\
\hline
\end{tabular}


All observed parameters show an increase in the intensity of international trade between Serbia and China. Serbia's exports to China are still much lower than imports, but the import/export ratio has a positive trend (Table 5). The increase in the number of foreign trade entities between Serbia and China is also noticeable, with the opportunity to improve capacities and technology through this cooperation. Agreement between China and Serbia on economic and technical cooperation in infrastructure projects from 2009 gave impetus to the intensification of economic relations. It also resulted in participation in several infrastructure projects in the Republic of Serbia, such as the construction of Pupin Bridge (Zemun-Borca), TPP project Kostolac, the building of two sections of the Obrenovac-Ljig highway on Corridor 11, privatization of the Železara Smederevo and RTB Bor, etc. (CEAS, 2019).

Table 5. Number of Serbia's foreign trade entities dealing with China, 2013-2018 (source: Serbian Chamber of Commerce, 2019)

\begin{tabular}{|c|c|c|c|c|c|c|}
\hline & 2013 & 2014 & 2015 & 2016 & 2017 & 2018 \\
\hline Export & 133 & 143 & 183 & 215 & 262 & 281 \\
\hline Import & 7802 & 7975 & 8238 & 8953 & 9607 & 10162 \\
\hline
\end{tabular}

However, one of the controversial sides of the privatization of Železara Smederevo (Iron / Steel company) was highlighted by EUROFER (European Steel Industry Association) for fear that it would be possible to re-export Chinese products through this company. Besides, the concern of this European association and the EU is emphasized that Serbia is unofficially subsidizing this company through enabled low electricity price contrary to EU regulations. At the same time, the EU has doubts that prices are being dumped when they are sold on their market. For this reason, after Hestil took over Železara Smederevo, Brussels launched an investigation into dumping prices and fears that steel could come to the European market with dumping prices, which would distort competition within the EU. Such an accusation is called the "Trojan Horse" alluding to the effects that China, through Serbia and other countries, has caused under their Silk Road initiative indirectly in the European Union market. In 2018, Hestil made total exports of $\$ 780$ million, and this company is the second biggest Serbian exporter (Politico, 2018).

Consequently, the European Commission announced in January 2019 that the EU would introduce quotas on imports of steel from third countries. The measures aim to protect European steelmakers after producers around the world shifted trade to the European market because of earlier unilateral US measures that restricted steel imports to the US market (European Commission, 2019). However, after the January restrictions, quotas for steel imports into the European Union have been increased by 5\% since July 1, 2019 (Uprava carina, 2019). This tariff increase also applies to the import of steel from Železara Smederevo, which practically enabled the rise in exports from Serbia. Still, from the other side, this shows the potential market risk.

Another reason for Chinese investment in this part of the industry is ecology. Namely, the environmental regulations in Serbia are lower than the EU standards, which in these industries can be an essential factor in reducing the costs of exploration and production. Weaker environmental regulations can contribute to the concentration and development of these industries, but on the other hand, can have long-term adverse effects on the environment and human health. Significant investments in the area of transport infrastructure totalling $€ 8.4$ billion are highlighted as infrastructure and logistics support for capital investments (CEAS, 2019).

Locating the Serbian industry around Chinese capital investments can also contribute to the development of small, medium-sized and large enterprises. New markets that are indirectly "conquered" by participating in the new Silk Road initiative. Developing infrastructure can also stimulate investment inflows from other countries and develop an export-oriented domestic industry, thereby creating a better condition for long-term trade benefits and export growth of the Serbian economy. As this initiative is global, the economic decisions of other countries, especially the EU, will significantly influence Serbia's position on the new Silk Road. The domestic economy should adapt and follow the trend of this initiative, given the enormous potential benefit of participating in it. Table 6 shows the tendencies of certain macroeconomic variables and trade indicators of the Republic of Serbia since 2013, which can be considered as the official beginning of the new Silk Road. The results of the variables are not a direct consequence of this initiative, due to the large number of dependent and independent variables that define them and which are difficult to identify separately but can be seen as a trend in a given time interval.

The data in Table 6 show that GDP is growing in the observed period, as well as the volume of international trade, total exports and imports, but with a constant and growing trade deficit. Net FDI has seen a slight increase in recent years. 
Table 6. Macroeconomic variables of the Republic of Serbia, in Millions of US dollars, 2013-2018 (source: mWorld Bank, 2019; National Bank of Serbia, 2019)

\begin{tabular}{|c|c|c|c|c|c|c|}
\hline Year & GDP & Export & Import & $\begin{array}{c}\text { Total } \\
\text { FDI }\end{array}$ & $\begin{array}{c}\text { China's } \\
\text { FDI } \\
\text { (neto) }\end{array}$ & $\begin{array}{c}\text { China's } \\
\text { FDI \% }\end{array}$ \\
\hline 2013 & 48394 & 19285 & 23263 & 2059 & -0.562 & $0 \%$ \\
\hline 2014 & 47062 & 19803 & 23604 & 1999 & 109.34 & $5.47 \%$ \\
\hline 2015 & 39629 & 17941 & 20708 & 2343 & 26.74 & $1.14 \%$ \\
\hline 2016 & 40630 & 19753 & 21707 & 2355 & 76.91 & $3.27 \%$ \\
\hline 2017 & 44120 & 22299 & 25207 & 2895 & 116.76 & $4.03 \%$ \\
\hline 2018 & 50597 & 25691 & 30000 & 4107 & 217.6 & $5.30 \%$ \\
\hline
\end{tabular}

At the same time, FDI from China recorded significant growth rates observed by years. As a result, the share of FDI from China in total FDI increased and in 2018 amounted to $5.3 \%$ of total FDI in the territory of the Republic of Serbia. This trend of inflow of investments from China can undoubtedly have a positive effect on the country's macroeconomic situation and deficit reduction. Still, their volume must reach greater participation. Concerning foreign investment in the territory of Serbia, the share of FDI from EU countries participating with more than two-thirds of the total amount of FDI in Serbia, which is still dominant. While on the other hand, the potential for growth of Chinese investments is far higher, considering the amounts of funds earmarked for investments under the new Silk Road initiative.

The main advantages of the Silk Road for the Serbian economy are evident in improved logistics, through investments in railway and road infrastructure. Besides, Chinese capital is invested in the development of small, medium-sized and especially, large enterprises. It results in investment inflows from other countries and contributes to the development of the export-oriented domestic industry. Export from Serbia to China increased and, at the same time, the import/export ratio has a positive trend. All of this contributes to the intensification of good economic relations between Serbia and China. From the other side, disadvantages of this initiative, primarily because of significant capital projects, contributed to potentially long-term adverse effects on the environment and human health. Besides, there were problems with exports of steel to the EU market, due to unfair competition and dumping prices, which can be a potential risk for Serbian export.

\section{Conclusions}

The growing global economic importance of the new Silk Road initiative, creation of conventional markets and the enhancement of transport and logistics infrastructure will influence countries to continue and intensify cooperation with China and other countries within the "Belt and Road". General advantages of the new Silk Road can be seen in new investments, improved logistics infrastructure, innovations and new technologies, as well as in new economic integrations, competitive advantages and rising trade. Regarding disadvantages, the authors suggest - "probability of destroying job", while on the other hand due to the sales increase in the China market help to other countries to rise job places. There is also the probability of negative impact on ecology due to significant capital investments followed by poor environmental regulation.

Another problem could be the risk of external debt and overdependence on Chinese influence and the possibility of neglecting other European economies due to the orientation towards cooperation with China. For China, this is a chance to diversify international economic and geopolitical relations, to access new markets, and place funding, especially in EU countries. On the other hand, European countries are becoming a meeting place for new FDIs, new employment and long-term development projects, thus creating an environment for continued economic growth and development in the future. The effects of participating in the new Silk Road initiative can bring innovations and adaptability to local conditions, also as sustainability and stability. Trade effects are evident through the continued increase in foreign trade between the EU and China.

Active participation and development opportunity of Southeast Europe started to be realized through a series of agreements in which the Republic of Serbia also participates. Given Serbia's geographical location and the historical circumstances of its everlasting division between East and West, and its current aspirations for EU accession, but also the political need to maintain close relations with China, the "Belt and Road" initiative represents a significant chance to find the most economically favourable long-term development strategy. The development of transport infrastructure will enable the utilization of the logistics potential on the Silk Road, which in its continuation may find its way to European countries by rail and road through Serbian territory. Another form of cooperation is through Chinese investment, especially in 
large-scale capital projects. This current situation offers a chance to further exploit of Serbian position at one of China's breakthrough logistics hubs. In the last few years, China started to invest in Serbia, and through FDI increased its share in total FDI. Besides, the volume of foreign trade between those two countries has increased significantly since the launch of the "Belt and Road" initiative.

Further efforts must be directed towards the continued progress of co-operation and the improvement of Serbia's foreign trade position. Especially in the area of reducing the international trade deficit, which can be stimulated through export growth, both to China and to other countries involved in this development project. Besides, there is an increase in the number of market players involved in international trade between Serbia and China, which further contributes to the strengthening of economic relations.

The limitations of this paper relate to the fact that this initiative is relatively new and that more substantial effects and evaluations that are more accurate can be expected over a more extended period. Future research may focus on a comparative analysis of the real impacts in different economies on the new Silk Road initiative.

\section{References}

Autor, D. H., Dorn, D., \& Hanson, G. H. (2013). The China syndrome: Local labor market effects of import competition in the United States. American Economic Review, 103(6), 2121-2168. https://doi.org/10.1257/aer.103.6.2121

Bloom, N., Draca, M., \& Van Reenen, J. (2016). Trade induced technical change? The impact of Chinese imports on innovation, IT and productivity. The Review of Economic Studies, 83(1), 87-117. https://doi.org/10.1093/restud/rdv039

CEAS. (2019, Jul). Analiza bilateralnih odnosa Srbije i Kine i njihov uticaj na nastavak demokratizacije. https://www.ceas-serbia.org/sr/publikacije/8271rasomon-novi-ceas-izvestaj-analiza-bilateralnihodnosa-srbije-i-kine-i-njihov-uticaj-na-nastavakdemokratizacije-eu-integracija-i-saradnje-srbije-sanato-i-zemljama-clanicama

Chen, W. (2017). "One Belt One Road": building and promoting China's voice in global economic governance (in Chinese). Beijing Shi, Ren min chu ban she.

Dauth, W., Findeisen, S., \& Suedekum, J. (2016). Adjusting to globalization-Evidence from workerestablishment matches in Germany (CEPR Discussion Paper No. DP11045).

https://ssrn.com/abstract=2717594

Dimitrijević, D. (2018). Odnosi Srbije i Kine na početku 21. veka. Međunarodni problemi, 70, 49-67. http://repozitorijum.diplomacy.bg.ac.rs/357/
Dimitrijević, D., \& Jokanović, N. (2016). China's 'New Silk Road' development strategy. Review of International Affairs, 67(1161), 101-123.

Egger, P., \& Larch, M. (2008). The bilateral and multilateral trade effects of road and railway transport infrastructure. Munich, Germany: Ifo Institute for Economic Research. Ludwig-Maximilian University of Munich.

Elek, A., Wylie, J., \& D'Souza, S. (2017). The future of the belt and road: long-term strategic issues. Quinhai Institute for Innovative Research, Shenyang.

European Commission. (2019). Countries and regions. https://ec.europa.eu/trade/policy/countries-andregions/

European Parliament. (2018). China, the 16+1 format and the EU. European Parliamentary Research Service.

https://www.europarl.europa.eu/RegData/etudes/B RIE/2018/625173/EPRS_BRI(2018)625173_EN.p df

Eurostat. (2019). Share of EU in the World Trade. European Commission. https://ec.europa.eu/eurostat/statisticsexplained/index.php?title=International_trade_in_ goods\&oldid $=471715$

Hedge, Z. (2017). China's Mysterious Arctic Silk Road. https://oilprice.com/Geopolitics/International/Chin as-Mysterious-ArcticSilk-Road.html

International Trading Centre. (2019). https://www.trademap.org/Country_SelProductCo untry.aspx?nvpm

Jane, C. C. (2011). Performance evaluation of logistics systems under cost and reliability considerations. Transportation Research Part E: Logistics and Transportation Review, 47(2), 130-137. https://doi.org/10.1016/j.tre.2010.09.012

JP Putevi Srbije [PE Roads of Serbia]. (2018, February 21). Godišni izveštaj saobraćaja. JP „Putevi Srbije”. https://www.putevi-srbije.rs/index.php

Ladjevac, I., \& Djordjević, B. (2016). Possibilities for promoting interconnectivity between China and Central and Eastern European countries. The Review of International Affairs, 67(1161), 65-79.

Li, J., \& Huang, Z. (2019). On the way to the Silk Road: trade, investment, and finance in emerging economies. Journal Emerging Markets Finance and Trade, 55(14), 3131-3133. https://doi.org/10.1080/1540496X.2019.1644104

Li, Y., \& Schmerer, H. J. (2017). Trade and the New Silk Road: opportunities, challenges, and solutions. Journal of Chinese Economic and Business Studies, 15(3), 205-213. https://doi.org/10.1080/14765284.2017.1347473

Limão, N., \& Venables, A. J. (2001). Infrastructure, geographical disadvantage, transport costs and trade. The World Bank Economic Review, 15(3), 451-479. https://doi.org/10.1093/wber/15.3.451 
Marić, B. (2017). Novi "put svile". Anali poslovne ekonomije, 9(17), 37-44. https://doi.org/10.7251/APE1717037M

Mišev, G., Stanojević, P., \& Jeftić, Z. (2017). Neki aspekti bezbednosti srpske infrastrukture na „Novom putu svile”. Novi put svile: evropska perspektiva, 193-207.

https://doi.org/10.18485/fb_nps.2018.ch12

Narodna Banka Srbije [National Bank of Serbia]. (2019). Godišnji izveštaj o stabilnosti finansijskog sistema u 2018. godini. NBS. https://www.nbs.rs/internet/latinica/90/fs.html

Nazarko, J., Czerewacz-Filipowicz, K., \& Kuźmicz, K. A. (2017). Comparative analysis of the Eastern European countries as participants of the new silk road. Journal of Business Economics and Management, 18(6), 1212-1227. https://doi.org/10.3846/16111699.2017.1404488

Paulain, L. (2011, August 29). China's new Balkan strategy. Centre for Strategic and International Studies - CSIS.

https://www.csis.org/analysis/chinas-new-balkanstrategy

Politico. (2018, July). Beware Chinese Trojan horses in the Balkans, EU warns.

https://www.politico.eu/article/johannes-hahnbeware-chinese-trojan-horses-in-the-balkans-euwarns-enlargement-politico-podcast/

Republički zavod za statistiku [Statistical Office of the Republic of Serbia]. (2020, March). https://www.stat.gov.rs/sr-Latn/vesti/20190930spoljnotrgovinska-robna-razmena-avgust-2019

Rifkin, J. (2016). One Belt One Road: ushering in a green internet plus Third Industrial Revolution in China, the European Union and across Eurasia. Forum PA.

Rimmer, P. J. (2018). China's Belt and Road Initiative: underlying economic and international relations dimensions. Asian-Pacific Economic Literature, 32(2), 3-26.

https://doi.org/10.1111/apel.12247

Simić, J. (2015). Ekonomski pojas novog puta svile: kineski prodor na zapad ili odgovor na azijske izazove. Međunarodni problemi, 67(2-3), 196216.

Szczudlik-Tatar, J. (2013, October 4). China's charm offensive in Central and Eastern Europe: The implementation of its "12 Measures" strategy. PISM Bulletin.

https://www.files.ethz.ch/isn/171360/Bulletin\%20 PISM\%20no\%20106\%20(559),\%204\%20October $\% 202013 . p d f$

Uprava carina [Customs Administration]. (2019). http://www.carina.rs/lat/PoslovnaZajednica/Porekl oRobe/Stranice/Kvote.aspx

World Bank. (2019). https://lpi.worldbank.org/international

World Economic Forum. (2016). https://www.weforum.org/agenda/2016/09/this-ishow-chinas-new-silk-road-initiative-could-impacteuropean-trade

Xia, X., \& Shen, E. (2016). China overseas investment strategies on "One Belt One Road" (in Chinese). Beijing Shi, Jing ji guan li chu ban she.

Zeldin, W. (2015, May 14). China: new guidelines for cooperation signed with central and Eastern European countries. http://www.loc.gov/lawweb/servlet/lloc_news?disp 3_1205404250_text

Žujović, B. (2015, September 4). Ekonomski pojas duž Puta svile i pomorski put svile za XXI vek - retrospektiva. Nova Srpska Politička Misao: Časopis za političku teoriju i društvena istraživanja. http://www.nspm.rs/savremeni-svet/ekonomskipojas-duz-puta-svile-i-pomorski-put-svile-za-Xxivek-retrospektiva.html 